\title{
Canada's proposed natural-gas plant stirs more controversy
}

\author{
Lawsuits and a new study raise questions about the project's environmental impact.
}

Lesley Evans Ogden

11 November 2016

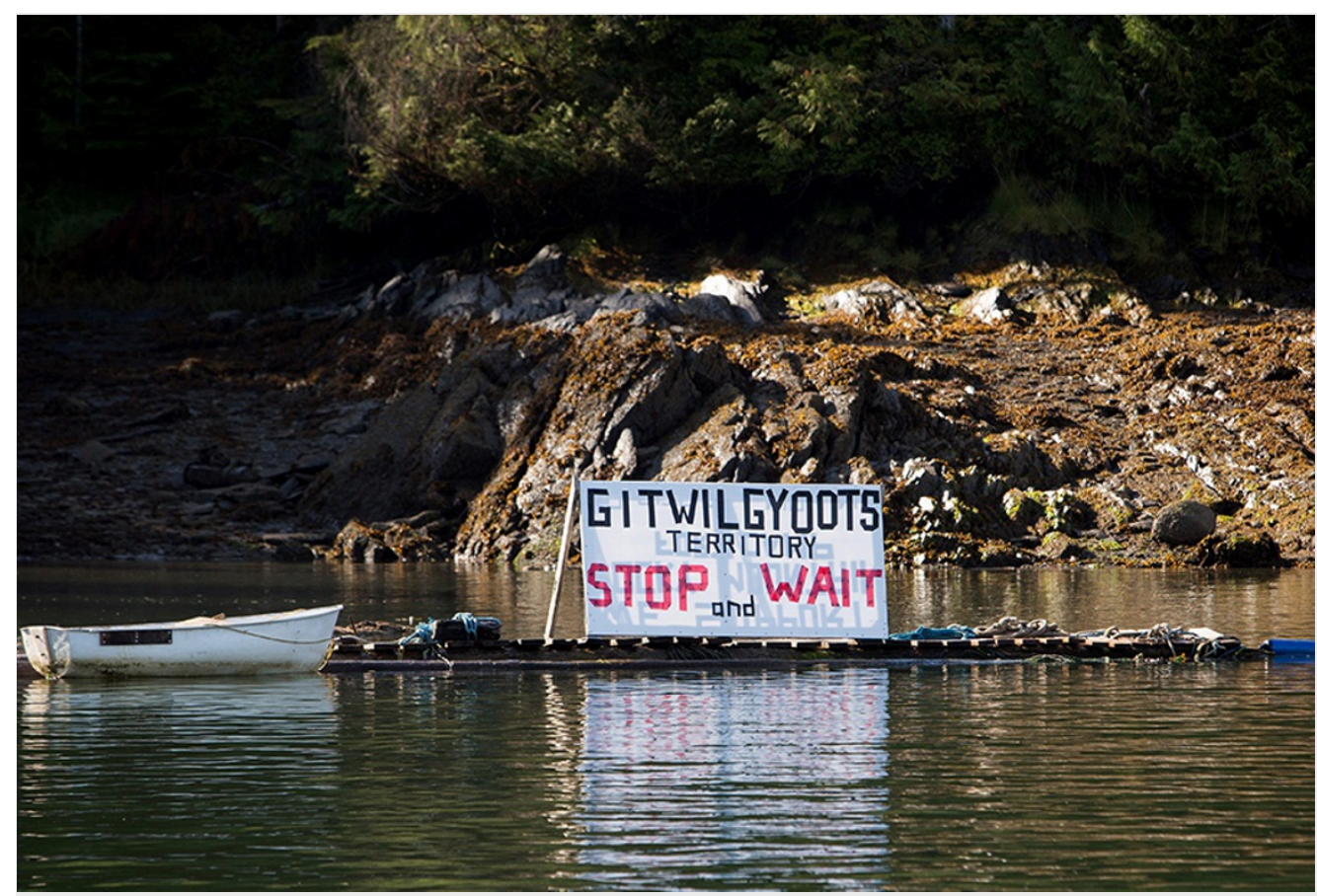

Ben Nelms/Bloomberg via Getty Images

A protest sign floats on the waters around Lelu Island, British Columbia, proposed site of a large liquefied natural gas plant.

The controversy surrounding a proposed liquefied natural-gas plant in British Columbia, Canada, continues to intensify. The project, which the Canadian government approved in September, now faces three separate lawsuits. And new research at the proposed site on the Skeena River estuary reveals that some salmon species spend over a month in the area, feeding and growing during their migration to the sea.

In contrast, a marine fish survey conducted by Stantec Consulting on behalf of the project characterized the habitat as low value. Although Fisheries and Oceans Canada (DFO) rejected that conclusion, the agency determined that any harm from construction could be mitigated to produce only negligible impacts on salmon.

The Skeena natural-gas liquefaction and export facility would be one of Canada's largest resource-development projects. It is spearheaded by an international consortium led by PETRONAS, the Malaysian state oil company.

A study led by ecologist Jonathan Moore at Simon Fraser University in Burnaby, British Columbia now finds that the Skeena River estuary near the plant's proposed site is likely to be more valuable habitat for salmon populations than previously thought. The researchers used stable isotopes of sulfur, carbon and nitrogen as chemical clocks to estimate how long four salmon species spent in the area. They published their findings on 9 November in Marine Ecology Progress Series ${ }^{1}$.

\section{Pit stop}

Migratory salmon pick up a freshwater chemical signal from the area where they hatch. That signal slowly changes to the chemical signature of the more brackish river mouth, where the fish stop on their seaward migration. "Their placement along that chemical signature gradient can tell us how long they've been in the estuary," says Moore.

Understanding the stopover time is important, because it can tell environmental managers how important the area is to the fish, he adds. 
His team found that $25 \%$ of Chinook salmon (Oncorhynchus tshawaytscha) spent at least 33 days in the estuary, compared with 30,22 and 5 days for pink (O. gorbuscha), coho (O. kisutch) and sockeye (O. nerka), respectively.

These results confirm most of what scientists had suspected, says Charles Simenstad, a salmon expert at the University of Washington in Seattle. The study also presents a clearer picture of species such as pink and sockeye salmon that some thought didn't use estuaries very much, he adds.

\section{No say}

In three separate lawsuits filed on 27 October, environmental and indigenous groups criticized the environmental-assessment process, expressed concerns over the project's future greenhouse-gas emissions and highlighted a lack of universal support by indigenous groups. The lawsuits have requested a judicial review of the project's approval.

"It's being built at a location that I think most scientists would agree is the worst possible from the perspective of fish and fish habitat," says Chris Tollefson, executive director of the Pacific Centre for Environmental Law and Litigation in Victoria, British Columbia and legal counsel for the lawsuit launched by SkeenaWild Conservation Trust.

The Gitanyow and Gitwilgyoots First Nations argued in their lawsuits that the federal government failed to adequately include them in project consultations. Chief Yahaan (Donnie Wesley) of the Gitwilgyoots, one of a group of nine allied tribes, says that questions he asked about the impacts of the PNW LNG project went unanswered.

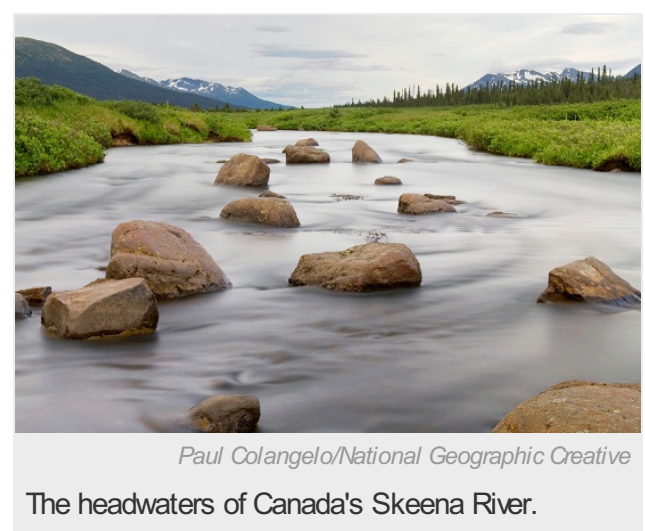

Sedimentologist Patrick McLaren of SedTrend in Brentwood Bay, British Columbia, says he also felt dismissed by government officials at a technical consultation meeting held by the Canadian Environmental Assessment Agency (CEAA) in January 2015. The First Nations group the Lax Kwalaams Band, representing the nine tribes, brought in McLaren as an independent consultant to review the reliability of a model used by PNW LNG to predict the construction's impact on river sediments. But when he tried to point out potential weaknesses in the PNG LNG model, McLaren says the CEAA chair of the meeting prevented him from discussing it.

\section{Proceed with caution}

The CEAA has, however, imposed more than 190 conditions under which this project will be allowed to proceed. Those include mitigation measures aimed at protecting fish species and their habitats, says Carmel Lowe, regional director of science for DFO in Nanaimo, British Columbia.

But some fish scientists are sceptical, given that 'offsetting' lost habitat has had mixed success, and is particularly tricky for areas that contain eelgrass, such as the Skeena River estuary. Whether lawsuits and the low price of natural gas will halt, or only temporarily postpone, this project on the Skeena estuary remains to be seen.

Nature | doi:10.1038/nature.2016.20975

\section{References}

1. Moore, J. et al. Mar. Ecol. Prog. Ser. 559, 201-215 (2016). 